\title{
Antifungal Activity of Mimosa pudica, Isolation and NMR Characterization of Bioactive Components
}

\author{
Okoronkwo Joseph Chukwu ${ }^{1}$, Ahamefula Anselm Ahuchaogu ${ }^{2}$, P. O. Ukaogo ${ }^{2}$, \\ A. I. Obike ${ }^{2}$ and John Bull Onyekachi Echeme ${ }^{1}$ \\ ${ }^{1}$ Department of Chemistry, Michael Okpara University of Agriculture, Umudike, Umuahia, Abia State, \\ Nigeria. \\ ${ }^{2}$ Department of Industrial Chemistry, Abia State University, Uturu, Nigeria.
}

\begin{abstract}
Authors' contributions
This work was carried out in collaboration between all authors. Author JBOE guided the research and the research paper was prepared under his supervision. Author OJC designed the study, wrote the protocol and wrote the first draft of the manuscript. Author AAA performed the spectroscopic analysis. Author AIO worked on the antifungal activity. Authors POU and AAA worked on literature search and review. All authors read and approved the final manuscript.
\end{abstract}

Article Information

DOI: $10.9734 /$ AJOCS/2017/34744 Editor(s):

(1) Fahmida Khan, National Institute of Technology Raipur, Chhattisgarh, India. Reviewers:

(1) JAVED INTEKHAB, Rohilkhand University, Shahjahanpur, India. (2) Lunesa Calijan-Pinzon, MSU-lligan Institute of Technology, lligan City, Philippines. Complete Peer review History: http://www.sciencedomain.org/review-history/20035

\section{ABSTRACT}

In this study, the whole plant of Mimosa pudica was extracted using absolute ethanol. The crude ethanolic extract and its isolated triterpenoid glycoside were tested for antifungal activity towards Aspergillus flavus and Trichophyton rubrum using Well Diffusion Method. At concentrations of $25-$ $100 \mathrm{mg} / \mathrm{mL}$, the extract possesses antifungal activity (from being partially active to very active) against Aspergillus flavus and Trichophyton rubrum. The TLC profile of the crude extract indicated many compounds with $\mathrm{R}_{F}$ values of $0.41,0.43,0.56,0.68,0.89$, and 0.90 . The isolation and purification were established using extensive thin layer and column chromatographic processes by employing various solvents with varied polarity. The results of thin layer and column chromatography gave rise to the isolation of a triterpenoid glycoside with $\mathrm{R}_{\mathrm{F}}$ value of 0.41 . The spectral analyses involving ${ }^{1} \mathrm{H}-\mathrm{NMR},{ }^{13} \mathrm{C}-\mathrm{NMR},{ }^{13} \mathrm{C}-\mathrm{DEPT},{ }^{135} \mathrm{COSY}, \mathrm{HMBC}, \mathrm{HMQC}$ and infrared were useful in proposing the structure of the compound. 
Keywords: Chromatography; antifungal activity; zone of inhibition; Mimosa pudica; secondary metabolites.

\section{INTRODUCTION}

The harmful side effects, high cost of other forms of treatment and their non availability to the poor populations who live in the remote areas are some of the reasons for the demand for herbal medicine. The increasing prevalence of multidrug-resistant strains of bacteria and the recent emergence of strains with reduced susceptibility to antibiotics raise the spectre of untreatable bacterial and viral infections. Thus, adding to the urgency to search for new infection fighting strategies (Sieradzki et al. [1]). Contrary to the synthetic drugs, antimicrobial substances of plant origin are not associated with many side effects and have an enormous therapeutic potential to heal many infectious disease (Iwu et al. [2]).

Mimosa pudica Linn is a creeping annual or perennial herb often grown for its curiosity value, as the compound leaves fold inward and drop when touched and reopens within minutes. It belongs to the Fabaceae family. The generic name Mimosa is derived from the Greek mimos, meaning "mimic", alluding to the fact that the leaves move in response to something moving against them. The specific epithet is taken from the Latin word pudica, meaning bashful or shrinking to contact (Barneby [3]). Mimosa is a genus of about 400 species of herbs and shrubs, in the subfamily Mimosoideae of the legume family Fabaceae. The plant is native to Brazil, but is now a pan tropical weed. The species is known by numerous common name including: sensitive plant, humble plant, shameful plant, touch-me-not, chuimui, and antplant. The vernacular names in the three major languages of Nigeria include: agboghomechieukwu (Igbo language), kamawalkinka (Hausa language) and ewe padimo or patomo (Yoruba language).

In Portugal, Africa, Rio de Janeiro, Sao Paulo City and other southern capitals, the name is nao-me-toque (touch-me-not). In Brazil, the name is dormideira (roughly "sleeper"). In Spanish, the name varies as mori-vivi or morivivi(roughly "I died, I lived") in the Dominican Republic, Puerto Rico and other Spanishspeaking Caribbean islands (Union County College Biology Department [4]). In Costa Rica, it is dormilona. In the Philippines, it is called "makahiya" which means "quite shy". It is putrimalu (shy princess) in Indonesia; pokoksemalu (shy plant) in Malaysia; nidikumba (sleeping plant) in Sri Lanka; mateloi (false death) in Tonga (Churchward [5]).

In south Asia many unrelated names are also common. In Hindi, it is known as chhui-mui (that which dies upon touch). In Bengali, the shrub is called lojjaboti (that bashful girl). In Malayalam, it is called thottavaadi (wilts by touch). In Marathi, it is called lazalu (shy). In Tamil, it is called thottasiningi (acts when touched) and in Kannada, it is known as muttidare muni (angered by touch). In Burmese (Myanmar) it is called htika-yoan (crumbles when touched). In Liberia, it is known as the picker weed (Union county College Biology Department, [4]).

This plant has a history of use for treatment of various ailments and the most commonly used plant part for this purpose is the root; but flowers, back and fruit can also be utilized. Several research works have been carried out to study about the phytochemical components of Mimosa pudica and also about the antimicrobial activity of the plant (Gandhiraja et al. [6]). Phytochemical studies on $M$. pudica have revealed the presence of alkaloids, fatty acids, non-protein amino acid (mimosine), flavonoids, C-glycosides, sterols, terpenoids, and tannins (Genest et al. [7]). Reported major pharmacological activities are:antiviral properties, aphrodisiac properties, antimicrobial properties, anti-venom activities, anti-hepatotoxic and antioxidant effects, diuretic effect, hyperglycemic effect, wound healing effect etc. (Amalraj and Ignacimuthu [8]). Some of the isolated secondary metabolites are bufadienolide, D-pinitol, norepinephrine, Pcoumaric acid, mimopudine, mimosine, potassium-5-O- $\beta$-glucopyranosy gentisate, etc. (Clark-Lewis and Porter, 1972), (Yadava and Yadav, 2001), (Ueda et al., 2000), (Sallaud et al., 1995), (Fromm and Lautner, 2007; Nair et al., 2007 and Genest et al., 1999).

Two well-known movements are observed in $M$. pudica: one is the very rapid movement of the leaves when it is stimulated by touch, heat and other external factors, and the second is the very slow, periodical movement of the leaves called nyctinastic movement which is controlled by a biological clock (Ueda et al. [9]). 


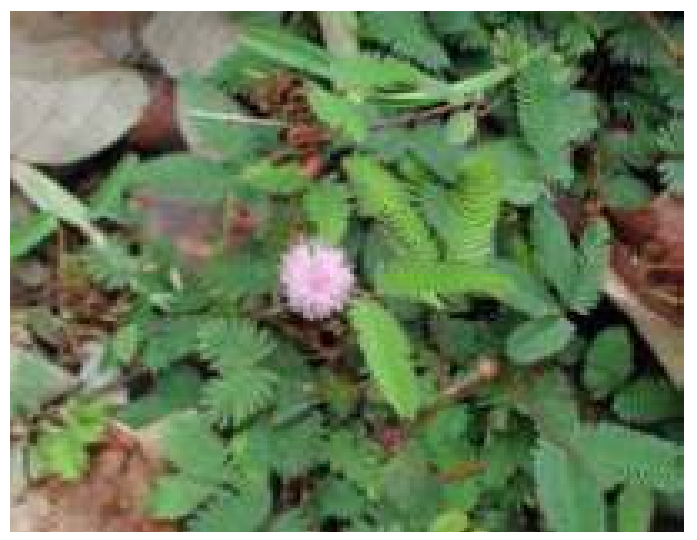

Mimosa pudica leaves and flower

\section{MATERIALS AND METHODS}

\subsection{Sample Collection and Preparation}

Fresh and wholesome parts of Mimosa pudica were collected during the month of October 2015, from Ndi-Ojigwe compound in Okoko Item, Bende Local Government Area of Abia State, Nigeria. The plant was identified and authenticated by Mr. I. Ndukwe in Plant Taxonomy Section of the Forestry Department of Michael Okpara University of Agriculture, Umudike, Nigeria. The fresh plant materials were dried under shade to prevent interference of uvradiation from the sun. Dried plant materials were powdered using electric blender. Then the powdered material was preserved in an air-tight container; ready for extraction.

\subsection{Extraction and Isolation of Plant Material}

Two (2) $\mathrm{kg}$ of the milled sample was percolated in $98 \%$ ethanol for 48 hours. Thereafter, it was filtered through Whatmann Filter Paper (No.42). The filtrate was concentrated using the Digital Heidolph Rotary-evaporator (4000 series); collecting $48.9 \mathrm{~g}$ of crude extract. The crude extract was partitioned between $\mathrm{CHCl}_{3}$ and water and a $\mathrm{CHCl}_{3}$-soluble fraction (16.3g) was obtained. The $\mathrm{CHCl}_{3}$ fraction $(10.0 \mathrm{~g})$ was then partitioned between petroleum ether (at 60${ }^{80} \mathrm{C}$ ) and aqueous methanol. The $\mathrm{CHCl}_{3}$ fraction $(5.0 \mathrm{~g})$ was then subjected to column chromatography over silica gel (200 mesh) and eluted gradually with $100 \mathrm{~mL}$ of petroleum ether, then petroleum ether: $\mathrm{CHCl}_{3}$ solvent system (95:5; 90:10; 85:15; 80:20; 75:25; 70:30; 65:35; $60: 40$; 55:45; 50:50; 40:60; 30:70; 20:80; 10:90), and $100 \mathrm{~mL} \mathrm{CHCl} 3$. Then $\mathrm{CHCl}_{3}$ : Methanol
$(90: 01 ; 80: 20 ; 70: 30 ; 60: 40 ; 50: 50 ; 40: 60 ; 30: 70$; $20: 80 ; 10: 90)$ and $100 \mathrm{~mL}$ methanol, followed by methanol: ethylacetate $(80: 20 ; 60: 40 ; 40: 60$; $20: 80$ ) and $100 \mathrm{~mL}$ ethyl acetate to yield twelve (12) major fractions. Chromatographic processes (partition chromatography, column chromatography and TLC) and spectroscopic techniques ( ${ }^{1} \mathrm{H}-\mathrm{NMR},{ }^{13} \mathrm{CNMR}$, COSY, DEPT, $H M B C, H M Q C$, and IR) were employed to isolate, purify, characterise and identify active constituents from the $\mathrm{CHCl}_{3}$ extracts of the sample.

\subsection{Antifungal Activity of Extracts from Mimosa pudica}

\subsubsection{Preparation of extract stock solution}

A stock of extract was prepared by dissolving $0.2 \mathrm{~g}$ of the plant extract in $2.0 \mathrm{~mL}$ of dimethyl sulphoxide (DMSO) to get a concentration of 100 $\mathrm{mg} / \mathrm{mL}$ of the stock solution. This stock solution was diluted with sterile distilled water to give concentration of $50 \mathrm{mg} / \mathrm{mL}$ and $25 \mathrm{mg} / \mathrm{mL}$.

\subsubsection{Fungal media (Potato dextrose agar)}

Potato slices $(200 \mathrm{~g})$ were boiled with distilled water. The potato infusion was used as water source of media preparation. Dextrose $(20 \mathrm{~g})$ was mixed with the potato infusion. Agar $(20 \mathrm{~g})$ was added as a solidifying agent. These constituents were mixed and autoclaved. The solidified plates were bored with 6-mm diameter cork borer. The plates with wells were used for the antifungal studies.

\subsubsection{Preparation of discs}

Filter paper discs (Whatmann No. 1) were sterilized in hot air oven inside glass Petri dishes at $160^{\circ} \mathrm{C}$ for 2 hours. Each disc was impregnated with $20 \mu \mathrm{l}$ of the plant extract solution at three concentrations: $25 \mathrm{mg} / \mathrm{mL}, 50 \mathrm{mg} / \mathrm{mL}$ and 100 $\mathrm{mg} / \mathrm{mL}$. The discs were placed in an incubator at $40^{\circ} \mathrm{C}$ and left for 2 hours to dry. They were used immediately and the remaining discs were stored at $4^{\circ} \mathrm{C}$.

\subsubsection{Disc diffusion test}

This was performed following the Kirby- Bauer method. Plates of Mueller Hinton Agar (MHA, Hardy Diagnostics, USA) were prepared according to manufacturer's instructions. The plates were dried in an incubator at $40^{\circ} \mathrm{C}$ for 30 min. using a sterile swab stick, standardized cells 
suspension containing an inoculums size of $5 \times 10^{8} \mathrm{CFU} / \mathrm{mL}$ was aseptically spread on the agar surface. The discs of the extracts and antibiotics were placed on the inoculated plates of each test organisms. The plates were incubated at 35$37^{\circ} \mathrm{C}$ for $16-18$ hours. The diameter of any clear zone of inhibition obtained around the discs was measured manually using a transparent ruler.

\subsection{Antifungal Activity of the Plant Extract}

The crude ethanolic extract and the isolated compound labeled MP-19 were tested against the fungal pathogens Aspergillus flavus and Trycophyton rubrum at concentrations of 25 $\mathrm{mg} / \mathrm{mL}, \quad 50 \mathrm{mg} / \mathrm{mL}$ and $100 \mathrm{mg} / \mathrm{mL}$. The experiment was replicated three times for each extract and antibiotic.

\section{RESULTS AND DISCUSSION}

\subsection{Antimicrobial Activity of Extract of Mimosa pudica}

The results of the antifungal assay of the crude ethanolic extract of M. pudica (MP) indicated that the extract exhibited (from being partially active to very active) antifungal activity against the tested microorganisms at all three different concentrations of $25 \mathrm{mg} / \mathrm{mL}, 50 \mathrm{mg} / \mathrm{mL}$ and 100 $\mathrm{mg} / \mathrm{mL}$. At $100 \mathrm{mg} / \mathrm{mL}$ the extract was very active against Aspergillus flavus. The zone of inhibition was recorded and presented in Table 1.

Table 2 shows the effect of the isolated compound labelled MP-19 on the microorganisms. The results of the experiment indicated that Aspergillus flavus and Trichophyton rubrum showed resistance against the isolated compound MP-19 from the crude ethanol extract of M. pudica. These results show that the isolated compound may not be responsible for the antifungal activity recorded in Table 1.

Compound MP-19 was eluted with chloroform and petroleum ether at the ratio of 50:50. Thin layer chromatography carried on MP-19 showed one spot $\left(R_{F} 0.41\right)$.

Analysis of $I R$ is shown in Table 3 . The $I R$ revealed $V_{\max } 2910 \mathrm{~cm}^{-1}, 1720 \mathrm{~cm}^{-1}, 1600 \mathrm{~cm}-1$ and $1250 \mathrm{~cm}^{-1}$ for aliphatic, carbonyl, olefinic, aromatic and ether respectively.

Analysis of ${ }^{1} \mathrm{H}-\mathrm{NMR}$ revealed the presence of olefinic protons at $3 \mathrm{H} 5.20$, cluster of peaks between $\precsim \mathrm{H} 0.8$ to $\precsim \mathrm{H} 2.35$ clearly indicated the triterpenoid structure, and two methoxy protons signals at $ð \mathrm{H} 4.058$ and $ð \mathrm{H} 4.239$. Then the presence of two anomeric protons at $ð \mathrm{H} 5.45$ and zH5.25 confirmed the presence of two sugars. The spectrum also showed the presence of aromatic protons atz $\mathrm{H} 5.043-ð \mathrm{H} 5.315$.

Table 1. Zone of inhibition $(\mathrm{mm})$ produced by crude ethanol extracts MP against the test organisms

\begin{tabular}{|c|c|c|c|}
\hline \multirow[t]{2}{*}{ Organisms } & \multicolumn{3}{|c|}{ Zone of inhibition ( $\mathrm{mm}$ ) at indicated concentration } \\
\hline & $25 \mathrm{mg} / \mathrm{mL}$ & $50 \mathrm{mg} / \mathrm{mL}$ & $100 \mathrm{mg} / \mathrm{mL}$ \\
\hline Aspergillus flavus & 13 & 16 & 22 \\
\hline Trichophyton rubrum & 11 & 14 & 17 \\
\hline
\end{tabular}

Table 2. Zone of inhibition $(\mathrm{mm})$ produced by fraction MP-19 against the test organisms

\begin{tabular}{|c|c|c|c|}
\hline \multirow[t]{2}{*}{ Organisms } & \multicolumn{3}{|c|}{ Zone of inhibition $(\mathrm{mm})$ at indicated concentration } \\
\hline & $25 \mathrm{mg} / \mathrm{mL}$ & $50 \mathrm{mg} / \mathrm{mL}$ & $100 \mathrm{mg} / \mathrm{mL}$ \\
\hline Aspergillus flavus & 0.0 & 0.0 & 0.0 \\
\hline Trichophyton rubrum & 0.0 & 0.0 & 0.0 \\
\hline
\end{tabular}

Table 3. Infra-red analysis of MP-19

\begin{tabular}{lll}
\hline IR absorption $\left(\mathbf{c m}^{-1}\right)$ & Functional group & Compound type \\
\hline 2910 & $-\mathrm{CH} 2$ & Aliphatic \\
1720 & $\mathrm{C}=\mathrm{O}$ & Carbonyl \\
1600 & $\mathrm{C}=\mathrm{C}$ & Aromatic \\
1250 & $\mathrm{C}-\mathrm{O}$ & Ether \\
\hline
\end{tabular}




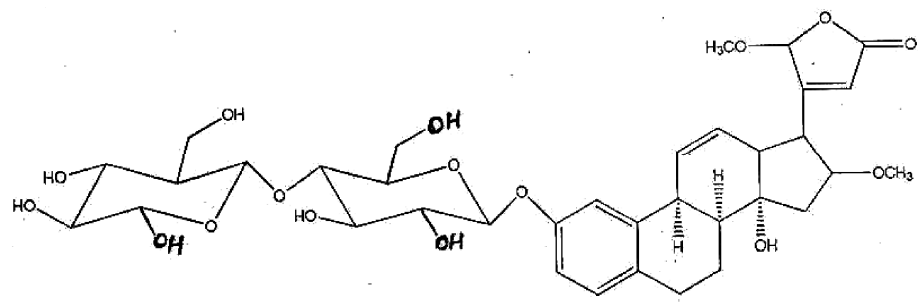

Fig. 1. MP-19

${ }^{13} \mathrm{C}-\mathrm{NMR}$ spectrum revealed the presence of six aromatic carbons at ${ }_{\mathrm{C}} 124.00, \mathrm{\delta} 126.08$,

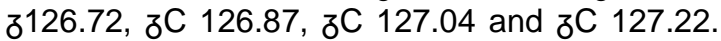
Methylene carbons chemical shift were seen at ъC 21.55 - ъC 22.60, methane carbon peaks were observed at ${ }_{\mathrm{C}} 25.38$ - ${ }_{\mathrm{C}} 33.17$, while the signal at ${ }_{\mathrm{C}} 172.93$ indicates the presence of carbonyl carbon, which is an integral part of the triterpenoid. Based on the chromatographic data, IR, NMR, COSY, DEPT, HMBC and HMQC, the structure of MP-19 was proposed as shown in above Fig. 1 with molecular formula $\mathrm{C}_{35} \mathrm{H}_{46} \mathrm{O}_{16}$.

\section{CONCLUSION}

In the present study, a triterpenoid glycoside was isolated from Mimosa pudica ethanol crude extracts. At concentrations of $25-100 \mathrm{mg} / \mathrm{mL}$, the extract possesses antifungal activity (from being partially active to very active) against Aspergillus flavus and Trichophyton rubrum, indicating that the plant contains potential antimicrobial components for the therapy of infections. Further investigation should be done to purify and isolate more bioactive components responsible for most of its documented pharmacological activities in order to promote the use of the plant in drug discovery.

\section{COMPETING INTERESTS}

Authors have declared that no competing interests exist.

\section{REFERENCES} 1. Sieradzki K, Robert RB, Haber SW,
Tomasz A. The development of vancomycin resistance in a patient with methicillin-resistant Staphylococcus aureus infection. N. Engl. Med. 1999;340(7):517523.

2. Iwu MW, Duncan AR, Okunji CO. New Antimicrobials of plant origin. In: J.J (Ed): Perspectives on new crops and new uses. ASHS Press. Alexandria, VA. 1999; 457462

3. Barneby R. Sensitive censitae: A description of the genus Mimosa Linnaeus (Mimosaceae) in the New World. New York Botanical Garden, New York; 1991;

4. Ueda M, Yamamura S. Angew. Chem. Int. Engl 39, 1400. Union County College Biology Department. "The Sensitive Plant"; 2008.

5. Churchward CM. Tongan dictionary. Tonga: Government Printing Press. 1959; 344.

6. Gandhiraja N, Sriram S, Meenna V, Kavitha Srilakshmi J, Sasikumar C, Rajeswari R. Phytochemical screening and antimicrobial activity of the plant extracts of Mimosa pudica L. against selected microbes. Ethnobotanical Leaflets. 2009; 13:618-24.

7. Genest S, Kerr C, Shah A, Rahman MM, Saif-E-Nasar GM, Nigam $P$, et al. Comparative bioactivity of two Mimosa species. Lat Am Caribb Bull med Aromat Plants. 2008;7:38-43.

8. Amalraj $\mathrm{T}$, Ignacimuthu S. Hyperglycemic effect of leaves of Mimosa pudica Linn. Fitoterapia. 2002;73:351-2.

9. Ueda M, Yamamura S. The chemistry of leaf movement in Mimosa pudica L. Tetrahedron. 1999;55:10937-48.

(c) 2017 Chukwu et al.; This is an Open Access article distributed under the terms of the Creative Commons Attribution License (http://creativecommons.org/licenses/by/4.0), which permits unrestricted use, distribution, and reproduction in any medium, provided the original work is properly cited.

Peer-review history:

The peer review history for this paper can be accessed here: http://sciencedomain.org/review-history/20035 